\title{
Congenial In Vitro $\gamma$-ray-Induced Mutagenesis Underlying the Diverse Array of Petal Colours in Chrysanthemum (Dendranthema grandiflorum kitam) cv. "Candid" ${ }^{+}$
}

\author{
Ambreena Din ${ }^{1, *} \mathbb{D}$, Zahoor Ahmed Qadri ${ }^{1}$, Muneeb Ahmad Wani ${ }^{1}{ }^{\mathbb{D}}$, Zahoor Ahmad Rather ${ }^{1}$, Shameen Iqbal ${ }^{1}$, \\ Sajid Ali Malik ${ }^{1}$, Peerzada Rashid Hussain ${ }^{2}$, Sadaf Rafiq ${ }^{1}$ and Imtiyaz Tahir Nazki ${ }^{1}$ \\ 1 Division of Floriculture and Landscape Architecture, Faculty of Horticulture, \\ Sher-e-Kashmir University of Agricultural Sciences and Technology of Kashmir, \\ Jammu and Kashmir 190025, India; drzahoorqadri@gmail.com (Z.A.Q.); \\ wanimuneeb05@gmail.com (M.A.W.); drzahoorrather@gmail.com (Z.A.R.); \\ shameeniqbal32@gmail.com (S.I.); maliksajidali92@gmail.com (S.A.M.); \\ sadaf.rbhat@gmail.com (S.R.); mitnazki@gmail.com (I.T.N.) \\ 2 Astrophysical Sciences Division, Nuclear Research Laboratory, Bhabha Atomic Research Centre, \\ Srinagar 190006, India; mutteebar@gmail.com \\ * Correspondence: dinambreena@gmail.com \\ + Presented at the 1st International Electronic Conference on Plant Science, 1-15 December 2020; \\ Available online: https://iecps2020.sciforum.net/.
}

\section{check for} updates

Citation: Din, A.; Qadri, Z.A.; Wani, M.A.; Rather, Z.A.; Iqbal, S.; Malik, S.A.; Hussain, P.R.; Rafiq, S.; Nazki, I.T. Congenial In Vitro $\gamma$-ray-Induced Mutagenesis Underlying the Diverse Array of Petal Colours in Chrysanthemum (Dendranthema grandiflorum kitam) $\mathrm{cv}$. "Candid". Biol. Life Sci. Forum 2021, 4, 21. https://doi.org/10.3390/ IECPS2020-08780

Academic Editor: Yoselin

Benitez-Alfonso

Published: 1 December 2020

Publisher's Note: MDPI stays neutral with regard to jurisdictional claims in published maps and institutional affiliations.

Copyright: (c) 2020 by the authors. Licensee MDPI, Basel, Switzerland. This article is an open access article distributed under the terms and conditions of the Creative Commons Attribution (CC BY) license (https:/ / creativecommons.org/licenses/by/ $4.0 /)$.

\begin{abstract}
Chrysanthemum (Dendranthema grandiflorum kitam.) is a leading flower with applied value worldwide. Flower color is an important trait that influences the commercial value of chrysanthemum cultivars. Developing new chrysanthemum cultivars with novel characteristics, such as new flower colors in a time- and cost-efficient manner, is the ultimate goal for breeders. Understanding the molecular mechanisms that regulate flower pigmentation may provide important implications for the rationale manipulation of flower color. To generate a diverse array of flower color mutants in chrysanthemum cv. "Candid" through mutagenesis, in vitro grown micro shoots were exposed to 10-, 20-, 30-, and 40-Gy gamma irradiation at 100 Gy per minute, and were evaluated for different parameters. The rhizogenesis parameters decreased with the increase in irradiation dose from $0 \mathrm{~Gy}$ to $40 \mathrm{~Gy}$, while a 10-Gy dose proved to record the minimum decline as compared to the control. Survival, leaf size, and the number of leaves on the plant ${ }^{-1}$ after the eighth week interval also decreased with the increasing trend of gamma irradiation dose but recorded a minimum decline in plants developed from shoots irradiated with a 10-Gy gamma irradiation dose, with respect to the control. The minimum delay in the number of days to floral bud appearance took under $10 \mathrm{~Gy}$, as compared to control. The highest number of flower color mutants were recorded under $10 \mathrm{~Gy}$ (light pink, orange pink, white, and yellow). Amountable mutation frequency on the basis of flower color was desirable in plants irradiated with the smallest dose of $10 \mathrm{~Gy}$.
\end{abstract}

Keywords: chrysanthemum; mutagenesis; gamma irradiation; mutants

\section{Introduction}

The chrysanthemum is a very popular and important cut flower crop grown all over the world in Japan, China, USA, France, UK, and India. It is a major horticultural crop and is the second largest in terms of cut flowers after roses, among the ornamental plants traded in the global flower market [1]. The complex genetic hetrozygosity make the cultivated chrysanthemum an unlimited source of new flower form and cultivars. The common garden chrysanthemum is hexaploid with 54 chromosomes [2]. It is propagated vegetatively and has a strong self-incompatibility system [3], hence new cultivars are difficult to obtain by crossing. Traditionally, new cultivars have been obtained from spontaneous mutations in vegetative reproduction, with some variations being more stable than others [4]. In the 
last few years, induced mutations and somaclonal variations derived from the tissue culture process have been employed as a new source of variability [5-10]. Although extensive work has been carried out to develop novelties in chrysanthemum through induced mutations using physical and chemical mutagens [11], there is always a need to explore the possibility of a new variety for floriculture trade. Mutation breeding by radiation has been widely used to upgrade well-adapted plant varieties and also to develop new variations within improved agricultural characteristics. Since most cultivated chrysanthemum cultivars are polyploids with high genetic heterogeneity, mutants with allied flower color, shape, floral size, and shape are often recovered. Allied flower colors with chimeric tissue can be easily induced by radiation and can be isolated using in vitro tools [1]. Mutation techniques are used because chrysanthemum is a vegetatively propagated hexaploid plant, which make it difficult to conduct the hybridization [12]. Genetic variation is essential in any plant breeding program for crop improvement. Mutation breeding is an efficient way to produce heritable change, particular for the flower color. Increasing demand for a new form of chrysanthemum has encouraged research to obtain new varieties. Mutation breeding by radiation, an agricultural application of nuclear technology, has been widely utilized to improve the well-adapted plant varieties by one or few important traits $[1,7,10,13]$. Commercially important traits in horticulture plants have been altered in a positive way by the various physical mutagens. Among the physical mutagens, gamma rays are widely used for inducing mutations in flowering plants due to their easy application and high efficiency. The physical irradiations have been used effectively for induction of mutation in chrysanthemums, with an optimum dose ranging from 1.0 to 3.0 Krads, depending upon the genotypes [14]. While mutation breeding offers various factors, such as a choice of material, character to be improved, type of mutagens, and its dose to be used, experimental procedures should also be considered. Thus, through mutation breeding, it is possible to induce a genetic variation for quantitative and qualitative characters that is heritable of sufficient magnitude and frequency of interest in the breeding program. Thus, the genetic variability created by mutation was studied for the development of new a cultivar in chrysanthemums having significant consumer preference. Therefore, with consideration to above factors, the present investigation entitled "Congenial in vitro $\gamma$-ray induced Mutagenesis underlying the diverse array of petal colours in chrysanthemum (Dendranthema grandiflorum kitam) cv. 'Candid'" was undertaken with an objective to generate a diverse array of flower color mutants through mutagenesis.

\section{Experiments}

\subsection{Materials and Methods}

Tissue-culture-developed micro shootlets of chrysanthemum cv. 'Candid' (Figure 1) were exposed to Cobalt ${ }^{60}$ gamma irradiation doses of $0,10,20,30$, and 40 Gy at 100 Gy per minute, and were allowed to raise vegetatively mutated generations first and second at 5 week intervals. Finally, shoots obtained from vegetatively mutated generation 2 were allowed for rooting and consequent acclimatization. Rooted shoots were allowed to grow in pots in the field to obtain new enviable color mutants, and rooting parameters were recorded in terms of percentage rooting and the number of roots per shoot. Survival (\%), leaf area plant ${ }^{-1}\left(\mathrm{~cm}^{2}\right)$, and the number of leaves on the plant ${ }^{-1}$ were recorded after 4 and 8 weeks of growth in the field. The number of days for a flower bud to appear was recorded at the initiation of flower bud appearance. Plant height was recorded at the end of full flower bloom. Flower colour was recorded in terms of difference between the parent flower and mutants obtained and the frequency of mutation was calculated on the basis of flower color, as the ratio between such desired or undesired color mutant and total plants irradiated with each gamma irradiation dose.

\subsection{Statistical Analysis}

Statistical analysis of the data collected for different parameters during the present investigation was subjected to analysis of variance for completely randomized design with four replications [15]. To satisfy model assumptions for analysis of variance, the percentage 
data were subjected to square root transformation, as suggested by [16]. The means were separated by the Duncan multiple range test.

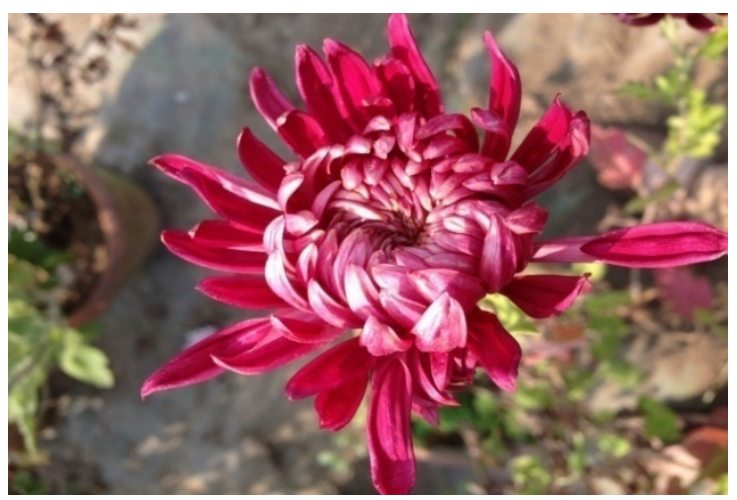

Dendranthemum morifolium L. cv. "Candid"

Figure 1. Chrysanthemum cultivar selected for the investigation.

\section{Results and Discussion}

\subsection{Influence of $\gamma$-rays on Rhizogenesis and Percent Survival}

The irradiation doses had an enervating effect on all the parameters of rooting in comparison to the control. A significant decrease in the mean rooting per cent and the number of roots shoot ${ }^{-1}$ in all the irradiation treatments in comparison to the control was observed. Among irradiation treatments, a minimum decline in rooting and the number of roots were recorded under a 10-Gy dose, followed by $20-$ and $30-G y$ irradiation doses. The maximum decline in rooting and the number of roots were registered with a 40-Gy dose (Figure 2a,b). Rhizogenesis is a process of dedifferentiation of specific pre-determined cells near the vascular bundles. These results suggest that any damage to cell division ability will have a negative effect on the dedifferentiation of cells and subsequent reorganization into root primordia. This may result in failure of rooting or delayed emergence of roots. Furthermore, [17] also reported that increased doses of gamma irradiation (from 20 to 50 Gy) decreased the rooting percentage of carnation cv. 'Espana'. Radiation treatments also delayed root initiation significantly in comparison to the control. Furthermore, [18] observed delayed root initiation of carnation shoots of cv. 'Scania' appeared under 1.00, 1.50 , and $2.00 \mathrm{~K}$-rads gamma irradiation doses. The deleterious effects of radiations also showed a significant decline in root number per shoot under 10 to $30 \mathrm{~Gy}$ treatments. Moreover, [19] also reported that most of the gamma irradiation treatments $(10,20,30$, and $40 \mathrm{~Gy}$ ), with or without NAA in the rooting medium, decreased the number and the length of roots in the carnation cultivars "Medea", "Candela", and "Picaro". All of the above quoted studies seem closer with the findings recorded in the present study. Survival of rooted shoots at the end of the fourth week was significantly minimizedby the shoots treated with a 40-Gy dose against the control, followed by a 30- and 20-Gy dose. Under the minimum dose of $10 \mathrm{~Gy}$, there was a minimum decline in the survival of shoots at the end of the fourth week over control. At the end of the eighth week, shoots treated with a 10-Gy dose recorded maximum survival, followed by a 20- and 30-Gy dose (Figure 2c,d). Whereas, the lowest survival per cent was recorded in 40-Gy irradiated shootlets, corresponding to the heavy decline in comparison to the control. Furthermore, [20] obtained a 100\% survival when chrysanthemum plantlets transferred into thesoil were irradiated with 2.5 or $5 \mathrm{kGy}$. The deleterious chimera load carried by the plants leads to mortality in post-irradiation proliferative generations. Another reason might be the formation of low or reduced wax component on the post-irradiation plants. As the wax component determines the rate of water loss through the cuticle, the susceptibility of tissue-cultured plants to desiccation attributed to a reduction or absence of wax, acting as an antitranspirant. The epicuticular wax is reduced or absent on the carnation leaves of in vitro cultured plants compared to glasshouse or field-grown plants [21], but during acclimatization, the density of waxes 
increases as the humidity is lowered [22]. As a result, the irradiation impairs the epidermal skin of the plants, leading to low wax formation even during the acclimatization process, and hence leads to mortality.
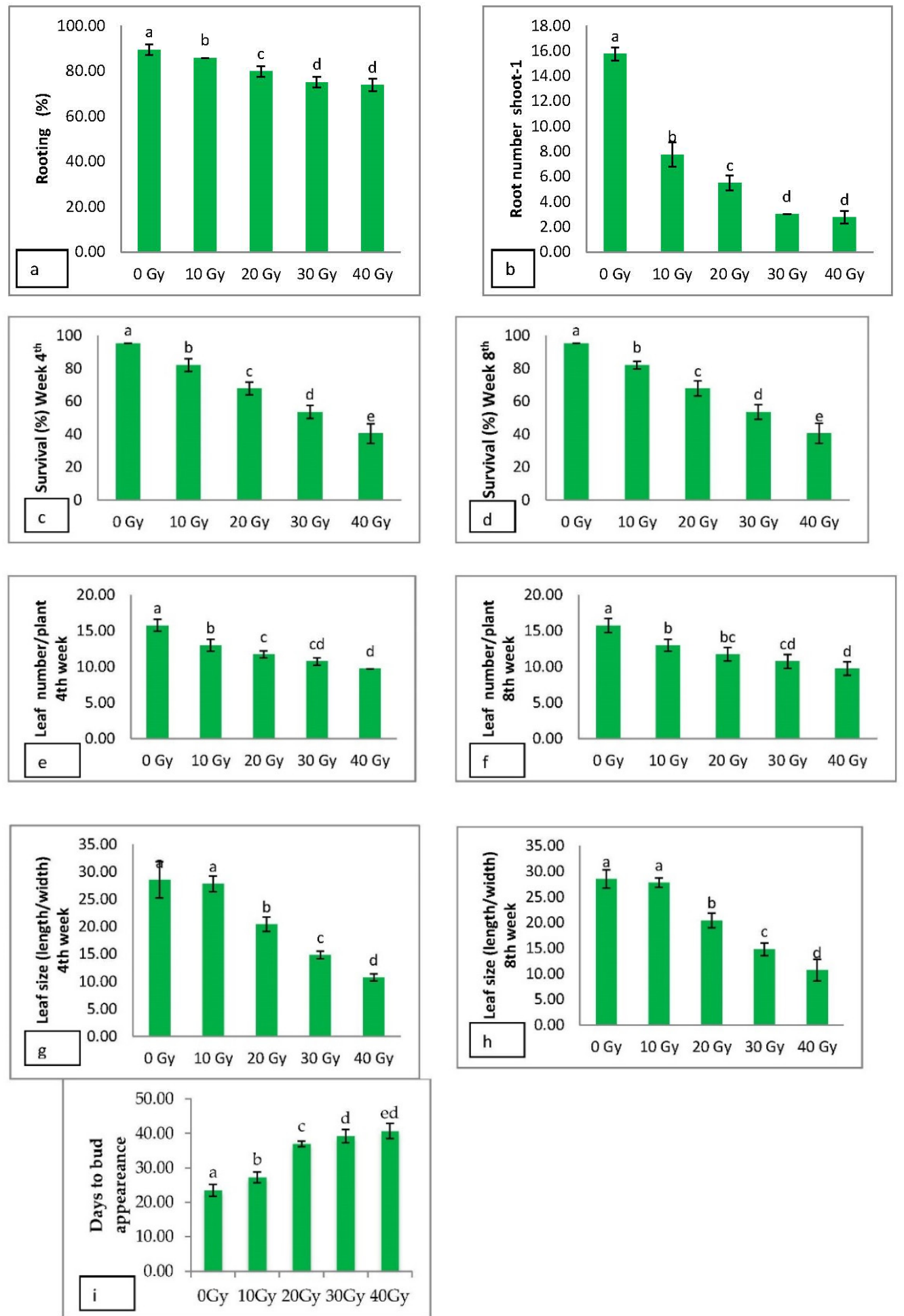

Figure 2. Influence of $\gamma$-rays on (a) the rooting percentage,(b) the root number per shoot, (c) the survival percentage of rooted shoots at the fourth week, (d) the survival percentage of rooted shoots at the eighth week, (e) the leaf number per plant at the fourth week, (f) the leaf number per plant at the eighth week, (g) the leaf size per plant at the fourth week (h) the leaf size per plant at the eighth week, and (i) the days to flower bud appearance. 


\subsection{Influence of $\gamma$-rays on Number of Leaves and Leaf Area}

Gamma irradiation treatments significantly recorded a decline in the leaf number on the plant ${ }^{-1}$ and the leaf size in both the intervals i.e., after 4 and 8 weeks, as compared to control. At the end of the fourth week, the minimum leaf number on the plant ${ }^{-1}$ and the size were registered under the highest dose of $40 \mathrm{~Gy}$, followed by 30 and $20 \mathrm{~Gy}$, and the lowest gamma irradiation dose $10 \mathrm{~Gy}$ recorded a minimum decrease in the leaf number and size, as compared to the control. At the end of the eighth week, both the leaf number as well as leaf size improved in all the gamma irradiation doses, including the control plants but recorded the similar trend of decline in both the parameters, as in the fourth week interval with the successive gamma irradiation doses (Figure 2e-h). The leaf area increment is a result of the growth of cells, mainly controlled by growth regulators (auxins). Higher exposure to gamma irradiation agitate synthesis of auxins hence leads to decreased leaf area. Furthermore, $[23,24]$ recorded biological damage in carnation on increasing the dose of radiation. In addition, [25] did this in tuberose; [26] in gladiolus; [27] in costus; [28] in carnation; [29] in chrysanthemums; [30] in gladiolus; [31] in chrysanthemums; and Ref. [32] in rose; all of which reported a decrease in the number of leaves with the increase in dosage of gamma irradiation. Whereas, [33] reported a reduction in leaf size in terms of length and width of plants treated with higher doses of gamma rays in variety "Otome Pink" and found that petiole length was shorter with increasing dose of mutagenic agents. Ref. [34] recorded that lower doses, such as 10 and 20 Gy, increased the leaf area, but 30 Gy did so more than in the control. In yet another study by [35], reduction in the leaf number was reported in Dendranthema grandiflorum kitamcv. "Gulmohar" under gamma irradiation dose range of 1.0-3.0 kR.

\subsection{Influence of Gamma Irradiation on Days to Floral Bud Appearance}

With the increment of each dose of irradiation (Figure 2i), there was a significant delay in the days to bud appearance, in comparison to control plants (23.50). Under 10, 20, and 30 Gy doses, days to bud appearance was recorded as 27.25, 37.00, and 39.25, respectively. Whereas, days to bud appearance under the last dose of 40 Gy recorded the highest at 40.75 , which represented a maximum delay as compared to control. The results in the present study may be due to the disturbances in biochemical pathway which assists in the synthesis of flower-inducing substances and hence a delay in flowering. The results in the present study are in concurrence with the findings of [36], who observed delayed flowering behavior after irradiating rooted cutting of small decorative type chrysanthemum cv. "Kalyani Mauve". In another study, [14] also observed a significant delay in the days to bud formation, buds showing color, and days for full bloom in the treated plants of ten chrysanthemum cultivar as compared to the control. Similar results were obtained by [31] in chrysanthemum cv. "Pooja".

\subsection{Influence of Gamma Irradiation on Flower Colour and Mutation Frequency}

Regarding the color of flowers after irradiation, desired color mutants were selected only from the plants irradiated with a 10-Gy dose, which evolved 60 per cent of pink, 15 per cent of orange pink, 10 per cent white, 5 per cent of light yellow, and the remaining 10 per cent were the same as the control, i.e., showing an original red color (Figure 3a-d). Higher doses of 20, 30, or 40 Gy produced either distorted red buds or distorted red (Figure 3e,f). Color mutants under 20,30, and 40 Gy were undesirable. The results in the present study may be due to physiological changes which occur in plants. Hence, delayed flowering can occur at higher doses due to this inhibitory effect. This can be attributed to the fact that no chimeric growth was developed in the shoot as result of mutagenesis. Shoots or tissue without chimeric growth lead to non-formation and different color variation in petals, as reported by [37], in chrysanthemums. This quoted observation is in close conformity to the present study. Regarding the mutation frequency in chrysanthemum flowers on the basis of flower color, data revealed that there was a highly desired mutation frequency amounting to 90 per cent when the plants were irradiated with a 10-Gy dose. Whereas, 
under 20, 30, and 40 Gy doses, flower mutation frequency, although recorded in per cent, produced undesirable mutants. The results obtained in the present study are in accordance to the findings of [38], who reported an increase in the mutation frequency when the plants were UV-irradiated.

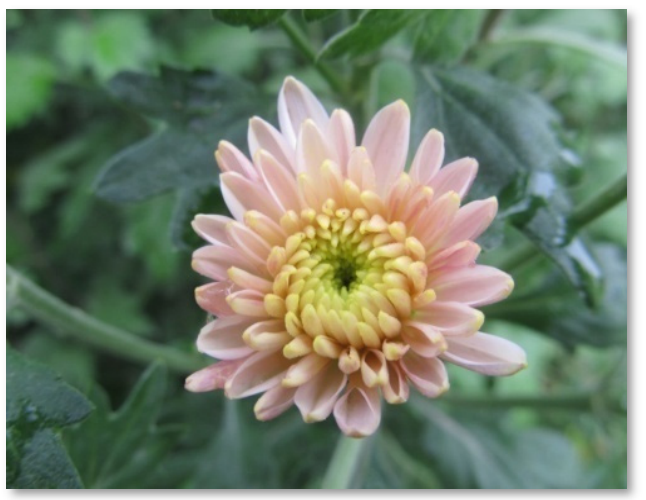

(a) Light pink

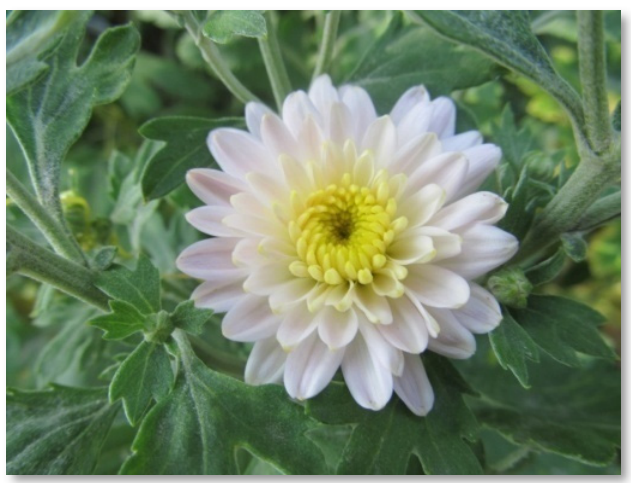

(c) White

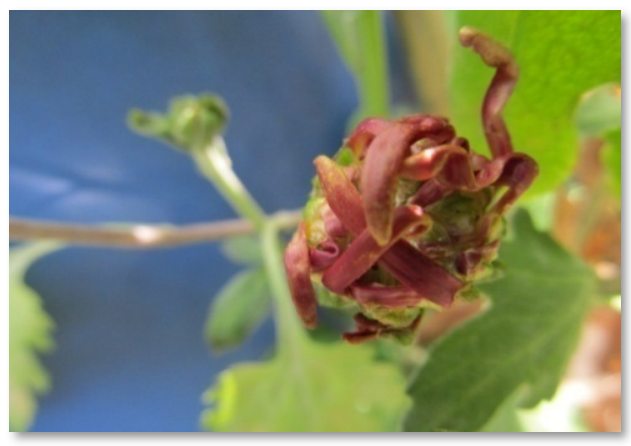

(e) Distorted red bud

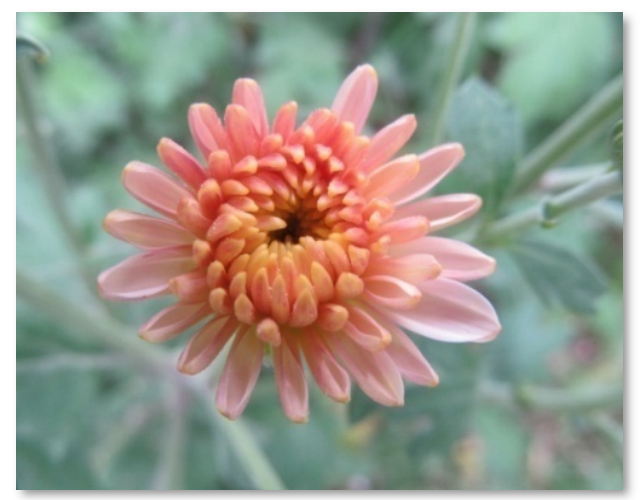

(b) Orange pink

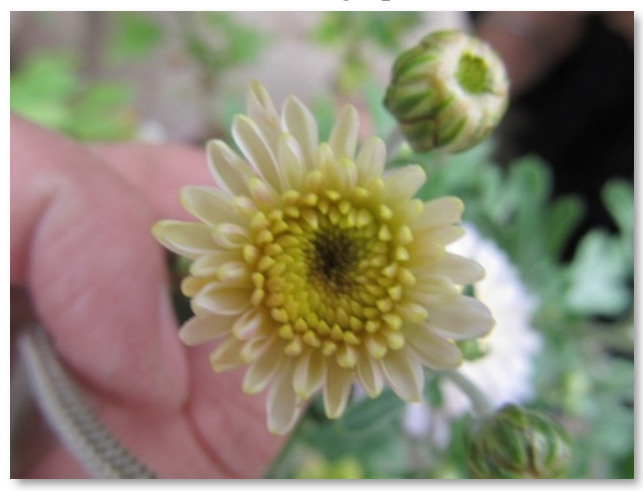

(d) Light yellow

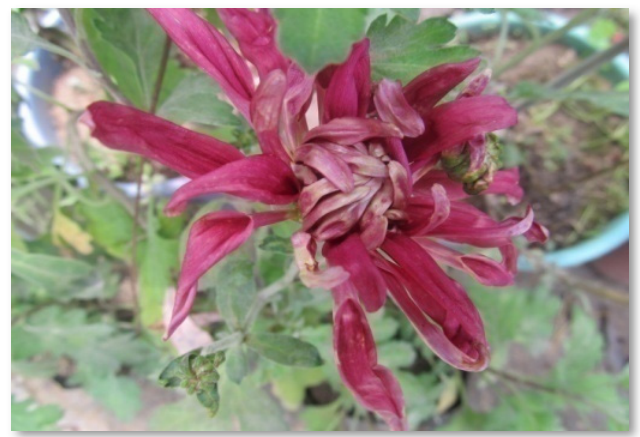

(f) Distorted red floret

Figure 3. Mutants of ${ }^{60} \mathrm{Co}$ gamma irradiation doses.

\section{Conclusions}

The study concludes that irradiation of a 40-Gy dose resulted in a significant decrease in days to floral bud appearance and mutation frequency. The highest number of desired mutants, with respect to flower color (light pink, orange-pink, white, and yellow) and the highest mutation frequency, were recorded in shoots irradiated with $10 \mathrm{~Gy}$. Hence, $10-G y$ gamma irradiation treatment is congenial for mutagenesis in chrysanthemums $\mathrm{Cv}$. "Candid".

Supplementary Materials: The poster presentation is available online at https:/ / www.mdpi.com/ article/10.3390/IECPS2020-08780/s1. 
Author Contributions: This work was carried out in collaboration between all authors. A.D. and Z.A.Q. designed the study and wrote the protocol. A.D., M.A.W., Z.A.R. and P.R.H. collected the data and performed the laboratorial analysis. A.D. analyzed the data and wrote the first draft of the manuscript. S.I. and S.A.M. managed the analysis of the study. S.R. and I.T.N. performed the statistical analysis. All authors have read and agreed to the published version of the manuscript.

Funding: This research received no external funding.

Institutional Review Board Statement: Not applicable.

Informed Consent Statement: Not applicable.

Data Availability Statement: Not applicable.

Acknowledgments: I am highly thankful to Maulana Azad National Fellowship for financial assistance during the whole programme.

Conflicts of Interest: The authors declare no conflict of interest.

\section{References}

1. Kumar, S.; Prasad, K.V.; Choudhary, M.L. Detection of genetic variability among chrysanthemum radiomutants using RAPD markers. Curr. Sci. 2006, 90, 1108-1113.

2. Wolff, K. RAPD analysis of sporting and chimerism in chrysanthemum. Euphytica 1996, 89, 159-164. [CrossRef]

3. Richards, A.J. Plant Breeding Systems; George Allen and Unwin: London, UK, 1986.

4. Miñano, H.S.; González-Benito, M.E.; Martin, C. Molecular characterization and analysis of somaclonal variation in chrysanthemum cultivars using RAPD markers. Sci. Hortic. 2009, 122, 238-243. [CrossRef]

5. Schum, A.R. Mutation breeding in ornamentals: An efficient breeding method. Acta Hortic. 2003, 612, 47-60. [CrossRef]

6. Datta, S.K.; Misra, P.; Mandal, A.K.A. In-vitro mutagenesis a quick method for establishment of solid mutant in chrysanthemum. Curr. Sci. 2005, 88, 155-158.

7. Jain, S.M.; Spencer, M.M. Biotechnology and mutagenesis in improving ornamental plants. In Floriculture, Ornamental and Plant Biotechnology: Advances and Topical Issues; da Silva, J.A.T., Ed.; Global Science Books: Isleworth, UK, 2006; Volume 1, pp. 589-600.

8. Zalewska, M.; Lema-Rumińska, J.; Miler, N. In vitro propagation using adventitious buds techniques as a source of new variability in Chrysanthemum. Sci. Hortic. 2007, 113, 70-73. [CrossRef]

9. Jain, S.M. Mutagenesis in crop improvement under the climate change. Rom. Biotechnol. Lett. 2010, 15, 88-106.

10. Barakat, M.N.; Abdel, F.R.S.; Badr, M.; El-Torky, M.G. In-vitro culture and plant regeneration derived from ray florets of Chrysanth morifolium. Afr. J. Biotechnol. 2010, 9, 1151-1158.

11. Broertjes, C.; Van-Harten, A.M. Application of mutation breeding methods in the improvement of vegetatively propagated crops. An interpretive literature review. In Developments in Crop Science; Elsevier Scientific Publishing Company: Amsterdam, The Netherlands, 1978; p. 316.

12. Dwimahyani, I.; Widiarsih, S. The effects of gamma irradiation on the growth and propagation of in vitro chrysanthemum shoot explants (cv. Yellow Puma). At. Indones. 2010, 36, 45-49. [CrossRef]

13. Chatterjee, J.; Mandal, A.K.A.; Ranade, S.A.; Teixeira-da-Silva, J.A.; Datta, S.K. Molecular systematics in Chrysanthemum $\times$ grandiflorum (Ramat) Kitamura. Sci. Hortic. 2006, 110, 373-378. [CrossRef]

14. Dilta, B.S.; Sharma, Y.D.; Gupta, Y.C.; Bhalla, R.; Sharma, B.P. Effect of gamma rays on vegetative and flowering parameters of chrysanthemum. J. Ornam. Hortic. 2003, 6, 328-334.38.

15. Gomez, K.A.; Gomez, A.A. Statistical Procedures for Agricultural Research; Wiley-Interscience Publications: New York, NY, USA, $1983 ;$ p. 84.

16. Steel, R.G.D.; Torrie, J.H. Principles and Procedures of Statistical Analysis; McGraw Hill Book Co. Inc.: New York, NY, USA, 1980; pp. 232-251.

17. Singh, K.P.; Singh, B.; Raghava, S.P.S.; Misra, R.L.; Kalia, C.S. In vitro induction of mutation in carnation through gamma irradiation. J. Ornam. Hortic. 1999, 2, 107-110.

18. Sooch, M.; Arora, J.S.; Singh, K.; Gosal, S.S. Effect of gamma ray irradiation on in vitro multiple shoot formation and establishment of carnation plants. J. Ornam. Hortic. 2000, 3, 118-119.

19. El-Sharnouby, M.E.; El-Khateeb, M.A.A. Effect of BA, NAA and gamma irradiation on the production of three cultivars of carnation (Dianthus caryophyllus L.) through tissue culture. Ann. Agric. Sci. Moshtohor 2005, 43, 1937-1948.

20. Broertjes, C.; De-Jong, J. Radiation induced male sterility in daisy type of Chrysanthemum morifolium Ramat. Euphytica 1984, 33, 433-434.

21. Sutter, E.; Langhans, R.W. Epicuticular wax formation on carnation plantlets regenerated from shoot-tip culture. J. Am. Soc. Hortic. Sci. 1979, 104, 493-496.

22. Wardle, K.; Dobbs, E.B.; Short, K.C. In vitro acclimatization of aseptically cultured plants to humidity. J. Am. Soc. Hortic. Sci. 1983, $108,386-389$. 
23. Simard, M.H.; Ferriere, N.M.; Silvy, A. Variants of carnation (Dianthus caryophyllus L.) obtained by organogenesis from irradiated petals. Plant Cell Tissue Organ Cult. 1992, 29, 37-42. [CrossRef]

24. Cassels, A.C.; Walsh, C.; Periappuram, C. Diplontic selection as a positive factor in determining the fitness of mutants of Dianthus 'Mystere derived from X-irradiation of nodes in in vitro culture. Euphytica 1993, 70, 167-174. [CrossRef]

25. Gupta, M.N.; Sumiran, R.; Shukla, R. Mutation breeding of tuberose Polianthus tuberose L. In Use of Radiations and Radioisotopes in Studies of Plant Productivity, Proceedings of a Symposium Held at GB Pant University of Agriculture and Technology, Pantnagar, 12-14 April 1974; Department of Atomic Energy, Food and Agriculture Committee: Bombay, India, 1975; pp. $169-179$.

26. Misra, R.L.; Bajpai, P.N. Mutational studies in gladioli (Gladiolus) I. Effect of physical and chemical mutagens on sprouting and survival of corms. Haryana J. Hortic. Sci. 1983, 12, 1-6.

27. Gupta, M.N.; Laxmi, V.; Dixit, B.S.; Srivastava, S.N. Gamma rays induced variability in Costus Speciosus. Prog. Hortic. 1982, 14, 193-197.

28. Acharya, N.N.; Tiwari, D.S. Effect of MMS and gamma rays on seed germination, survival and pollen fertility of Hamatocactus setispinus in $\mathrm{M}_{1}$ generation. Mysore J. Agric. Sci. 1996, 3, 10-13.

29. Siranut, L.; Peeranuch, J.; Arunee, W.; Surin, D.; Prapanpongse, K. Gamma ray induced morphological changes in Chrysanthemum (Chrysanthemum morifolium). Agric. Nat. Sci. 2000, 34, 417-422.

30. Srivastava, P.; Singh, R.P.; Tripathi, V.K. Response of gamma radiation $\left(60^{\circ} \mathrm{C}\right)$ on vegetative and floral characters of gladiolus. $J$. Ornam. Hortic. 2007, 10, 135-136.

31. Misra, P.; Banerji, B.K.; Kumari, A. Effect of gamma irradiation on chrysanthemum cultivar 'Pooja with particular reference to induction of somatic mutation in flower colour and form. J. Ornam. Hortic. 2009, 12, 213-216.

32. Kahrizi, Z.A.; Kermani, M.J.; Amiri, M.E.; Vedadi, S. Identifying the correct dose of gamma-rays for in vitro mutation of rose cultivars. In Acta Horticulturae, Proceedings of the XXVIIIth International Horticultural Congress on Science and Horticulture International Symposium on Micro and Macro Technologies for Plant Propagation and Breeding in Horticulture; Fabbri, A., Rugini, E., Eds.; International Society for Horticultural Science: Leuven, Belgium, 2010; Volume 923, pp. 121-127.

33. Kumari, K.; Dhatt, K.; Kapoor, M. Induced mutagenesis in Chrysanthemum morifolium variety 'Otome Pink' through gamma irradiation. Bioscan 2013, 8, 1489-1492.

34. Mahure, H.R.; Choudhry, M.L.; Prasad, K.V.; Singh, S.K. Mutation in chrysanthemum through gamma irradiation. Indian J. Hortic. 2010, 67, 356-358.

35. Dilta, B.S.; Sharma, Y.D.; Dhiman, S.R.; Verma, V.K. Induction of somatic mutations in chrysanthemum by gamma irradiation. Int. J. Agric. Sci. 2006, 2, 77-81.

36. Datta, S.K.; Banerji, B.K. Gamma ray induced somatic mutation in chrysanthemum cv. 'Kalyani Mauve'. J. Nucl. Agric. Biol. 1993, 22, 58-61.

37. Langton, F.A. Chimerical structure and carotenoid inheritance in Chrysanthemum morifolium (Ramat.). Euphytica 1980, $29,807-812$. [CrossRef]

38. Siavash, H.A.; Jirair, C.; Jalil, K. The effects of UV radiation on some structural and ultrastructural parameters in pepper (Capsicum longum). Turk. J. Biol. 2009, 34, 122-125. 